\title{
PROTECTION RIGHTS FOR THE BRAND IN A PRODUCT
}

\author{
Desi Febriani \\ 175100042P \\ Fakultas Komputer, 448757150 \\ desifebriani.student@umitra.ac.id
}

\begin{abstract}
Protection of intellectual property rights is very important for ongoing development in Indonesia. Protected intellectual property rights in Indonesia may be brands, licenses, copyrights, patents or industrial designs. Whereas Patent is a special right granted by the State to the inventor for his findings in the field of technology for a certain period of time carrying out his own invention to give his consent to others to do so (Law No. 6 of 1989).

In Indonesia, the rights of the brand were first applied to the Industriele Eigendom Kolonien Regulations in 1912, this provision was valid until 1961 (UUNo.21 about corporate and commercial brands).

In 1992 there was only Law No. 19 and amended by Law No. 15 of 2001 According to Law No.15 of 2001 article 1 paragraph 1 the right of the brand is a sign in the form of images, names, words, letters, numbers, arrangement of colors, or a combination of elements elements that have distinguishing features and are used in the trading of goods or services.
\end{abstract}

Keywords: Copyrights and Brands. 


\section{QUIZ Selected Section Class}

\section{A. INTRODUCTION}

\section{Brand Rights}

\section{a. Understanding of Brands}

Checking (English: branding) is the process of creating or leaving a particular trace mark in the minds and hearts of consumers through various communication methods and strategies so that special meanings and feelings that have an impact on consumers' lives (Wijaya, 2011; 2012; 2013) are created. The branding activity is an implementation of the brand communication strategy and is part of the brand development (value) process. Checking comes from the brand's basic words. The American Marketing Association (AMA) defines a brand as "a name, term, sign, symbol, or design, a combination of them, intended to identify the goods and services of a seller or to differentiate them from those of competitors "(Kottler, 2000: 404).

This is in line with what Aaker said that a brand is a name and / or symbol that distinguishes (in the form of a logo or symbol, stamp or packaging) to identify goods or services from a seller or group of sellers (Aaker, 1996).

The brand is the frontliner of a product, an initial display that makes it easy for consumers to recognize the product. In principle, the brand is the promise of the seller or manufacturer that continuously carries a series of display entities (performance), benefits (benefits) and services (service) to the buyer.

In the perspective of brand communication, Wijaya (2011; 2012;
2013) defines a brand as a trail mark left on the minds and hearts of consumers, which creates certain meanings and feelings (brand is a mark left on the minds and hearts of consumers, which creates a specific sense of meaning and feeling).

Thus, the brand is more than just a logo, name, symbol, trademark, or designation attached to a product. Brand is a promise (Morel, 2003). A brand is the number of an entity, a psychological connection that creates a bond of loyalty with a buyer / prospective buyer, and that includes perceived value added. Nilson (1998) mentions a number of criteria for calling a brand not just a name, including: the brand must have clear values, be identified with other brands, be interesting, and have a prominent identity.

This level is called the Hierarchy of Branding (Wijaya, 2011; 2012; 2013), starting from brand awareness (brand awareness), brand knowledge (brand knowledge), brand image (brand image), brand experience (brand-related experience), brand loyalty (brand loyalty) to brand spirituality (spirituality dimension related to the brand).

In Indonesia, the rights of the brand were first applied to reglement industriele eigendom colony 1912, this provision was valid until 1961 (UUNo.21 about corporate and commercial brands).

In 1992 there was only Law No. 19 and amended by Law No. 15 of 2001

According to Law No.15 of 2001 article 1 paragraph 1 , brand rights are signs in 


\section{QUIZ Selected Section Class}

the form of images, names, words, letters, numbers, arrangement of colors, or a combination of elements that have distinguishing features and are used in trade in goods or services.

\section{b. Types of Brands}

1. Trademarks

Trademarks are brands that are used on goods traded by a person or several people jointly or a legal entity to differentiate from other similar items.

2. Service brands

Service marks are brands that are used for services traded by a person or several people jointly or a legal entity to differentiate from other similar services.

3. Collective brands

Collective brands are brands that are used on goods and or services with the same characteristics, which are traded by a person or several people or legal entities jointly to distinguish between goods and or other similar services.

4. Brand certification

A certification brand is a trademark used to distinguish goods and services that follow a set of standards and have been authorized by the authority that gives the certificate.

5. Famous brand

A well-known brand is a brand that has been known for a long period of time and is considered well-known by the competent authorities of a country who are requested to protect the brand.

\section{c. Brand Elements}

- Brands have elements

- Has a distinguishing power

- Not public property
- Do not conflict with applicable laws and regulations, religious morality, morality or public order.

\section{d. Brand Subjects}

A person or several people together (collectively)

A legal entity or several legal entities collectively (collectively)

\section{e. Time period}

The period of brand legal protection is given for 10 years from the date of receipt and can be extended for the same period. Requests for extension are submitted in writing to the Director General of IPR within 12 months before the end of legal protection for the brand (9th year).

\section{f. Creating Brand Identity}

Steps in creating a brand identity:

Determine the purpose of the brand.

This goal is to influence the community to be willing to support the organization, take part in the program, use services or act in accordance with the law and rules.

Identify the target audience for the brand

Even though in reality many public people are exposed to our brands, the brand must be designed for certain groups in the community, who most want to be influenced.

Articulate the desired brand identity It is expected that the target audience thinks and feels what they are when they are exposed to our brand. In feeling we are encouraged to write pictures, words and feelings that are in 


\section{QUIZ Selected Section Class}

our minds towards various institutions, cities and nations.

Benefits to be highlighted for the target audience. Focus on benefits for the target audience, not the agency.

Determine the brand's position with competitors. What makes our brands deserve to be chosen compared to competing brands? By identifying competitors directly or indirectly.

Select brand elements

What names, slogans and colors will be associated with the brand? Is there consistent use of characters or packaging that will be a core element of the brand. In choosing brand elements, the valuation approach will be very useful, which will support the decisions that have been made regarding the brand's objectives, target audience, brand identity, brand promise and "brand positioning".

\section{g. Maintaining Brand Image}

Launch and manage identity and ensure that it produces the desired output and must have a passion for the brand in order to encourage using it to maintain it

Compiling Guidelines for Using Brand Elements

Set standards for using brand elements for all aspects from drawing to positioning the manufacturer's logo to public display. The guide also includes agreed upon color details, specifying specific numbers in the pantone matching system (PMS); positioning logo and tagline, including the type and size of letters used.

Audit and Managerial Brand Contact Points
Internal brand creation because the brand is not built only with promotion. Customers come to know the brand through a range of contacts and touchpoints: Interaction with institutional personnel and partners, experience online, telephone or make transactions on facilities provided, observation and personal associations when utilizing programs and services. Memastiakan Has Enough Visibility When launching a new brand or reviving a brand, exposure to adequate brand elements will determine the success of the brand in occupying the desired position of the customer's mind. Track and Monitor Brand Position

Supervision will include research that ideally measures brand image at prelaunch and compares it with results after launch.

Keep Using the Brand

When tracing the history of big brands, Will find the red thread is not creativity or brilliant ideas. The common thread is that the organization sticks to something that has gone on over time. The brand is still being cared for and the brand elements are protected during difficult times and are polished again when consumed by age.

\section{h. Brands that cannot be registered and which are rejected.}

There are several things that cause a brand not to be registered, namely if: Contrary to applicable laws, religious morality, decency or public order.

Does not have distinguishing power Has become public property. For example, skull marks above two crossed bones that are generally known 


\section{QUIZ Selected Section Class}

as a danger sign. This sign has become public property.

Is a statement or relating to goods or services that are requested for registration. For example a coffee brand or a picture of coffee for various types of coffee products.

In addition there are also several things that cause a brand application to be rejected, namely if

Having similarities in principle or in whole with the brands belonging to other parties that have been registered in advance for similar goods and services.

Have similarities in principle or in whole with well-known brands that belong to other parties for goods and or services of the like.

It has similarities in principle or in its entirety with known geographical indications.

Is or resembles the name of a famous person, photo or name of a legal entity owned by another person, except in written consent of the rightful person.

Is an imitation or resembles a name or abbreviation for a name, flag, emblem or symbol or a national or international institution, except with written approval from the competent authority. Is an imitation or resembles a sign or stamp or official stamp used by the State or government agency, except with written approval from the competent authority.

\section{i. Procedures for Requesting Trademark Registration}

Request

Application for trademark registration must be submitted in writing in the
Indonesian language to the Director General of Intellectual Property Rights, by the applicant or attorney, by attaching proof of payment for the brand registration fee. In the application letter must be stated:

a. Date, month and year.

b. Full name, nationality and address of the applicant.

c. Full name and address of the power of attorney if the application submits a brand through power.

d. Colors when the brand being applied for registration uses color elements.

e. The name of the country and the date of the first brand request in the event that the application is submitted with priority rights. Priority rights are the right of the applicant to submit an application originating from a country belonging to a certain organization to obtain recognition that the date of receipt in the country of origin is the priority date in the destination country which is also a member of both agreements, as long as the agreement is specify.

\section{Examination}

An examination of the completeness of the requirements for registration applications will be carried out by the Director General. If there are shortcomings, it will be asked to complete it. Conversely if the application is considered complete, the Director General will be given the date of receipt on the application letter. Furthermore, within a period of no more than 30 days from the date of receipt, the Director General will submit a request to the examiner to carry out a substantive examination (an examination of whether the registration application for the mark includes a 


\section{QUIZ Selected Section Class}

trademark that cannot be registered and includes applications that must be rejected). If the response and objection of the applicant or his proxy is accepted, the brand announcement will be made, on the contrary if it is not accepted, with the approval of the Director General a decree will be issued regarding the rejection of the application for registration.

Announcement

After a substantive inspection, and the examiner reports that the trademark registration application has been approved for registration, with the approval of the Director General, the application will be immediately announced in the Brand Official Gazette. Announcements must last for 3 months.

\section{j. Brand Removal}

Registered brands can basically be written off at the initiative of the Directorate General of Intellectual Property Rights or based on the request of the brand owner. This deletion is done if:

The mark has not been used for 3 consecutive years in the trade of goods or services since the date of registration or the last use.

Trademarks are used for types of goods or services that are not in accordance with the type of goods or services being applied for registration. Including the use of brands that do not match the brands listed.

\section{k. Legal Protection for Famous Brand Holders}

According to Sudikno Mertokusumo, he gave an overview of the notion of legal protection, namely all efforts made to ensure the existence of legal certainty based on the whole rules or rules that exist in a common life. The entire regulation can be seen from both the Law and the Ratification of the International Convention.

Based on the description above, the authors assume that the protection of intellectual property rights, especially towards Famous Brands are preventive and repressive.

Preventive protection is emphasized in efforts to prevent famous brands from being used by others incorrectly. The effort can be in the form of:

a. Rejection of registration by the Brand office.

b. Cancellation Registered brands violate the rights of other people's brands. As a result of registration errors carried out by brand office officers, a brand that should not be registered but ultimately listed in the general list of brands (DUM) that authorizes the brand. Even though these brands clearly violate other people's brands, because various things include similar or similar to other brands that have been previously registered.

Repressive protection focuses on giving penalties to those who have committed crimes and brand violations as stipulated in articles 90, 91, 94 of Law No. 15 of 2001 concerning Brands.

\section{l. Brand Function}

According to Endang Purwaningsih, a brand is used by manufacturers or brand owners to protect their products, either in the form of services or other merchandise, according to him a brand has the following functions:

1. Distinguishing function, namely differentiating one product from another company's product. 


\section{QUIZ Selected Section Class}

2. The reputation guarantee function, which is in addition to being a sign of the origin of the product, also personally connects the reputation of the branded product with the producer, while providing quality assurance for the product.

3. The function of promotion, namely the brand is also used as a means of introducing and maintaining the reputation of old products that are traded, as well as to dominate the market.

4. The function of investment stimulation and industrial growth, namely brands can support industrial growth through investment, both foreign and domestic in the face of free market mechanisms.

5. The function of the brand can be seen from the angle of producers, traders and consumers. In terms of brand manufacturers it is used to guarantee the value of their products, especially regarding quality, then their use. Traders, brands are used for the promotion of merchandise in order to find and expand the market, from the consumer side, the brand is used to make a choice of goods to be purchased.

Meanwhile, according to Imam Sjahputra, the function of the brand is as follows:

1. As a distinguishing sign (identifier).

2. Protecting the consumer community.

3. Maintain and secure the interests of producers.

4. Giving prestige because of reputation.

5. Quality assurance.

\section{B. CONCLUSION}

Every work that is born of brilliant thought that is useful to humans needs to be recognized and protected. For this reason, the IPR system is needed as a form of appreciation for the work.

Besides that the IPR system supports the establishment of a good documentation system for all forms of human creativity so that the possibility of producing the same technology or other works can be avoided or prevented.

With the support of good documentation, it is expected that the community can use it to the fullest for the needs of their lives or develop it further to provide higher added value. Now the community in submitting the application has not experienced any difficulties because the Government through DITJEN HAKI has carried out a lot of socialization both through the media and forums that have been formed. So that finally for the owner of the right not to worry about the loss caused by irresponsible people who want to take advantage of the popularity of the brand of a particular product.

\section{ACKNOWLEDGEMENT}

University Of Indonesia

University Of Mitra Indonesia

Telkom University

University Of Mellbourne

Saitama University

\section{REFERENCE (Based ISO 690 )}

[1] A. S. Putra And O. M. Febriani, "Knowledge Management Online Application In Pdam Lampung Province," In Prosiding 
International Conference On Information Technology And Business (Icitb), 2018, Pp. 181187.

[2] A. S. Putra, O. M. Febriani, And B. Bachry, "Implementasi Genetic Fuzzy System Untuk Mengidentifikasi Hasil Curian Kendaraan Bermotor Di Polda Lampung," J. Sist. Inf. Dan Manaj. Basis Data, Vol. 1, No. 1, Pp. 2130, 2018.

[3] O. M. Febriani And A. S. Putra, "Sistem Informasi Monitoring Inventori Barang Pada Balai Riset Standardisasi Industri Bandar Lampung," J. Inform., Vol. 13, No. 1, Pp. 90-98, 2014.

[4] Putra, Arie Setya. "2018 Artikel Struktur Data, Audit Dan Jaringan Komputer." (2018).

[5] Putra, A. S. (2018, July 17). Paperplain Fundamental Create Application With Borland Delphi 7.0 University Of Mitra Indonesia. Retrieved From Osf.Io/Pbrn9.

\section{E. REFERENCE (Based APA )}

Putra, A. S., Aryanti, D. R., \& Hartati, I. (2018, November). Metode SAW (Simple Additive Weighting) sebagai Sistem Pendukung Keputusan Guru Berprestasi (Studi Kasus: SMK Global Surya). In Prosiding Seminar Nasional Darmajaya (Vol. 1, No. 1, pp. 85-97).

Sari, D. P., Febriani, O. M., \& Putra, A. S. (2018, November). Perancangan Sistem Informasi SDM Berprestasi pada SD Global Surya. In Prosiding Seminar Nasional Darmajaya (Vol. 1, No. 1, pp. 289-294).
Putra, A. S. (2018). Paperplain: Execution Fundamental Create Application With Borland Delphi 7.0 University Of Mitra Indonesia.

Putra, A. S., Sukri, H., \& Zuhri, K. Sistem Monitoring Realtime Jaringan Irigasi Desa (JIDES) Dengan Konsep Jaringan Sensor Nirkabel. IJEIS (Indonesian Journal of Electronics and Instrumentation Systems), 8(2), 221232.

Darmawan, A., Yuliawati, D., Marcella, O., \& Firmandala, R. (2016). Sistem Absensi dan Pelaporan Berbasis Fingerprint dan SMS Gateway. EXPLORE, 7(1).

Febriani, O. M., Wahyuni, T., \& Yusuf, S. (2017). DESIGN OF WEBSITEBASED INFORMATION SYSTEM FOR EDOCUMENT ADMINISTRASI IN THE COMMUNITY SERVICE UNIT (A Case Study at Rajabasa District). INTERNATIONAL JOURNAL OF COMPUTERS \& TECHNOLOGY, 16(7), 7010-7020.

Febriani, O. M., \& Wahyuni, T. (2017, October). PERANCANGAN SISTEM E-DOCUMENT ADMINISTRASI LOGBOOK PENELITIAN PADA UNIT LAYANAN DI BANDAR LAMPUNG. In Prosiding Seminar Nasional Darmajaya (Vol. 1, No. 1, pp. 187-194).

Febriani, O. M., \& Permadi, A. B. (2017). Implementasi Sistem Aplikasi Data Bimbingan dan Pelanggaran Siswa pada Sekolah Menengah Atas di Lampung Tengah dengan Metode 
Analisis dan Desain Sistem

Terdistribusi (SSAD). EXPERT, 7(1).

Febriani, O. M., \& Ambarwati, L. (2015). PERANCANGAN APLIKASI PENGOLAHAN DATA PENJUALAN UKM KELANTING KHAS TELO DESA SIDOHARJO KECAMATAN JATI AGUNG KABUPATEN LAMPUNG SELATAN. Jurnal Teknologi Informasi dan Bisnis Pengabdian Masyarakat Darmajaya, 1(1), 77-95.

Febriani, O. M. (2015). Rancang Bangun Aplikasi Ecommercemenggunakan Freewebstore pada UKM Kelanting di Desa Sidoharjo Lampung Selatan. Prosiding Sembistek 2014, 1(02), 446-458. 